Short communication

\title{
A new distributional record for Gujarat state: Dipcadi saxorum Blatter
}

\author{
Rupesh R. Maurya ${ }^{1}$, Umerfaruq M. Qureshimatva ${ }^{1}$, Sandip B. Gamit ${ }^{1}$, \\ Rajdeo Singh $^{2}$ and Hitesh A. Solanki ${ }^{3}$ \\ ${ }^{1}$ Department of Botany, USSC, Gujarat University, Ahmedabad, Gujarat, India \\ ${ }^{2}$ St. Xavier's College, Mumbai University, Maharashtra, India \\ ${ }^{3}$ Department of Botany, USSC, Gujarat University, Ahmedabad, Gujarat, India
}

*Corresponding Author: ufmqureshi@yahoo.in

[Accepted: 24 August 2017]

[Cite as: Maurya RR, Qureshimatva YM, Gamit SB, Singh R \& Solanki HA (2017) A new distributional record for Gujarat state: Dipcadi saxorum Blatter. Tropical Plant Research 4(2): 330-331]

The Shoolpaneshwar Wildlife Sanctuary is an important protected area of Gujarat State, India, established in 1989, encompassing an area of $607 \mathrm{~km}^{2}$. along the north-eastern border of Bharuch district. The area lies between $21^{\circ} 03^{\prime} \mathrm{N}$ to $21^{\circ} 59^{\prime} \mathrm{N}$ latitude and $73^{\circ} 05^{\prime} \mathrm{E}$ to $74^{\circ} 10^{\prime} \mathrm{E}$ longitude at an altitude of 800 to $900 \mathrm{msl}$. Dense forest of the sanctuary constitutes catchment of two major irrigation dams viz. Sardar Sarovar and Karjan dams. Hills of the sanctuary are part of the Satpudas, where they merge with the Vindhayan. Dipcadi Medik. is represented by 41 species in the world, India as one of the center of diversity having 10 species with 4 varieties (Prabhugaonkar et al. 2009). Initially this genus was placed in Liliaceae, later in Hyacinthaceae and recent phylogenetic synthesis of Angiosperms available as APweb (Stevens 2001) and The Plant List (2013) places it now in Asparagaceae (sensu lato). With the publication of Red Data Book of Indian Plants six species of Dipcadi were assessed as threatened in India and thus prioritized for conservation (Dasgupta \& Deb 1981). Dipcadi saxorum Blatter is one of the six threatened plants in India which has been reported as endemic to Maharashtra earlier (Gaikwad et al. 2014). The specimens have been collected from Shoolpaneshwar forests area, Narmada District. Therefore, it forms a new distributional report to the Gujarat after Maharashtra (Shah 1978, Raghavan et al. 1981, Almeida 2009, Meena 2012). Voucher specimens RM-2036, 2037 are deposited in Herbarium, Department of Botany, USS, Gujarat University, Ahmedabad.

\section{ENUMERATION}

Depcadi saxorum Blatter J. Bombay Nat. Hist. Soc. 32: 736 1928. (Fig. 1)

Depcadi maharashtrensis Deb. \& Dasgupta J. Bombay Nat. Hist. Soc. 72: 822-3, t. 1, 1975.

Ornithogalum saxorum (Blatt.) Manning \& Goldblatt Edinburgh J. Bot. 60: 5522003.

Bulb tunicate. Scape about $50 \mathrm{~cm}$. long, terete, smooth. Racemes up to $20 \mathrm{~cm}$ long, rather lax, about 20 flowered. Bracts broadly ovate, long-acuminate, scarious, slightly finged near the base about $7 \mathrm{~mm}$ long. Pedicels stout, 1/2 longer than the bracts. Perianth 12-14 mm long, tubular, slightly trigonous, the 3 outer lobes connate for $1 / 3$ this length, linear-oblong, obtuse, recurved from about the middle with a thick, glandular tip, the 3 inner connate for almost 2/3 their length, $3 \mathrm{~mm}$ broad ovate-obtuse, with a recurved and slightly thickened tip, all lobes whitish with an olive coloured central band. Filaments about $1 \mathrm{~mm}$ long, slightly flattened; anthers 3 $\mathrm{mm}$ long, versatile, yellow. Pistil $10 \mathrm{~mm}$ long. Ovary $5 \mathrm{~mm}$ long, trigonous, clavate, shortly but distinctly stipitate; style very stout, $5 \mathrm{~mm}$. long minutely grandular upwards; stigma slightly thicker than style, 3-lobed. Capsule broader than long, deeply 3-sulcate, loculicidally 3-valved, membranous, stipitate, stalk stout, about 2.5 $\mathrm{m}$ long; 5 seeds slightly elliptical to nearly orbicular in outline, reaching $5 \mathrm{~mm}$ in diameter, compressed, with a raised margin, the lowest and top most in each cell plano-convex.

Flowering: July-August.

Fruiting: July-August. 

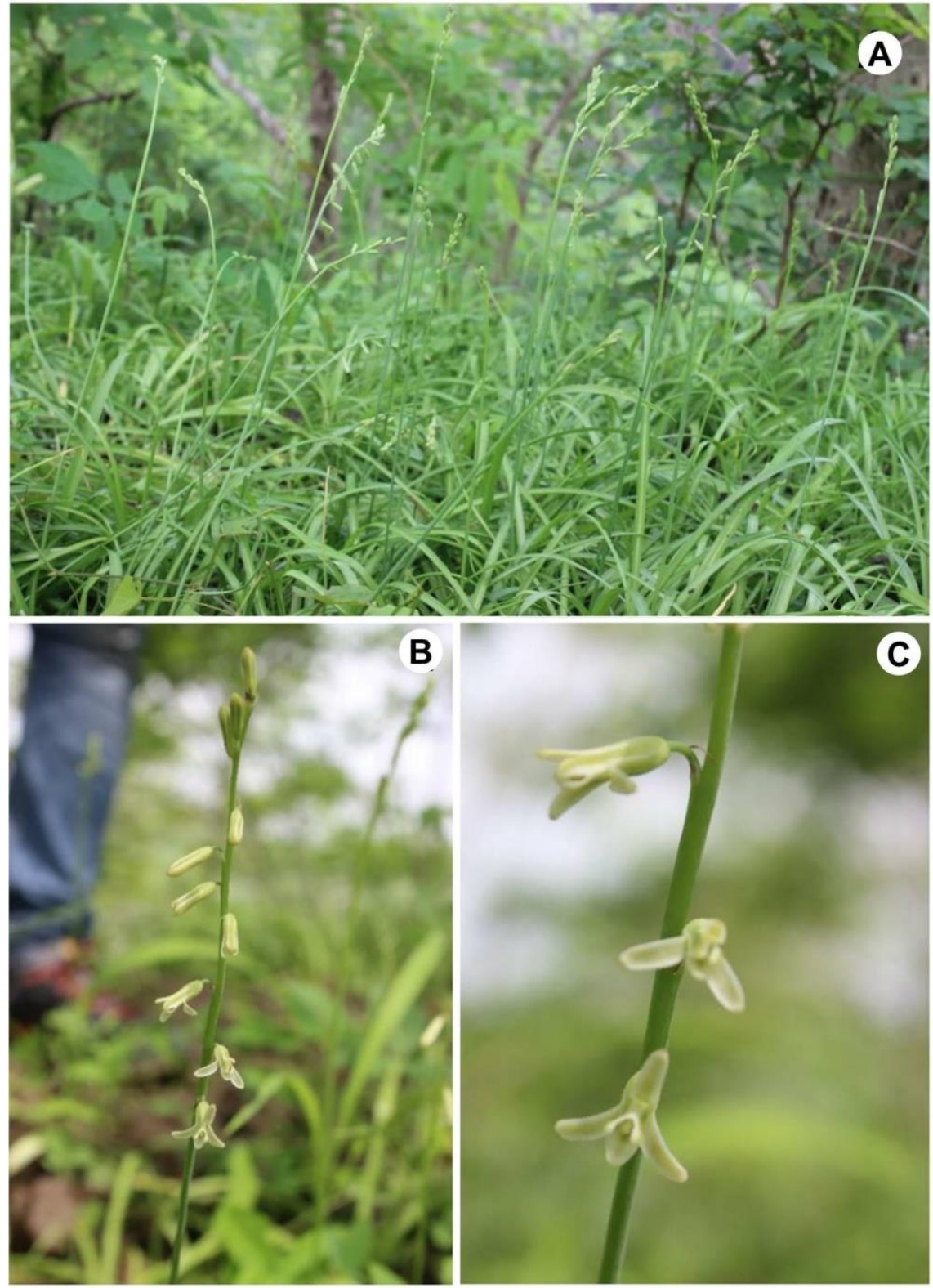

Figure 1. Photographs of Depcadi saxorum Blatter: A, Habit; B, Inflorescence; C, Flowers.

\section{REFERENCES}

Almeida MR (2009) Flora of Maharashtra. Orient press, Mumbai, Vol. 5 (A-B): pp. 177.

Dasgupta S \& Deb DB (1981) Liliaceae: Tribe Scilleae. Fascicles of Flora of India 7: 1-23.

Gaikwad S, Ramchandra G, Krushnadeoray G, Sampatrao G (2014) Endemic flowering plants of northern western Ghats (Sahyadri ranges) of India: check list. Check List 10(3): 461-472.

Meena SL (2012) A checklist of vascular plants of Banaskantha district, Gujarat, India. Nelumbo 54: 39-91.

Prabhugaonkar A, Yadav US \& Janarthanam MK (2009) Dipcadi goaense (Hyacinthaceae), a new species from the foothills of the Western Ghats, India. Kew Bulleten 64: 743-746.

Raghavan RS, Wadhwa BM \& Ansari MY (1981) A checklist of the plants of Gujarat. Botanical Survey of India 21(2): 51.

Shah GL (1978) The flora of Gujarat State. Vol-I and II, Sardar Patel University Press, Vidhyanagar, Anand, India.

Stevens PF (2001) Angiosperm Phylogeny Website. Version 12, July 2012. Available from: http://www.mobot.org/MOBOT/research/APweb/ (accessed on 3 August 2013).

The Plant List 2013. Version 1.1. Published on the Internet; http://www.theplantlist.org/ (accessed 21 May 2014). 